\title{
The Effect of Sulfur-Containing Humic Acid on Yield and Nutrient Uptake in Olive Fruit
}

\author{
Atoosa Danyaei ${ }^{1}$, Sara Hassanpour ${ }^{1}$, Mohammad Ali Baghaee ${ }^{2}$, Maryam Dabbagh ${ }^{3}$, \\ Mehrdad Babarabie ${ }^{*}$ \\ ${ }^{1}$ Dr. Shariaty Faculty, Technical \& Vocational University, Tehran, Iran \\ ${ }^{2}$ Agronomy, Shahed University and Company's Technical Manager of Khorram Bahar Atis, Tehran, Iran \\ ${ }^{3}$ Olericulture, Department of Horticulture, Gorgan University of Agricultural Sciences and Natural Resources, Gorgan, Iran \\ ${ }^{4}$ Young Researchers and Elite Club, Gorgan Branch, Islamic Azad University, Gorgan, Iran \\ Email: *antoniyom_3000@yahoo.com
}

How to cite this paper: Danyaei, A., Hassanpour, S., Baghaee, M.A., Dabbagh, M. and Babarabie, M. (2017) The Effect of Sulfur-Containing Humic Acid on Yield and Nutrient Uptake in Olive Fruit. Open Journal of Ecology, 7, 279-288.

https://doi.org/10.4236/oje.2017.74019

Received: March 24, 2017

Accepted: April 23, 2017

Published: April 26, 2017

Copyright (C) 2017 by authors and Scientific Research Publishing Inc. This work is licensed under the Creative Commons Attribution International License (CC BY 4.0).

http://creativecommons.org/licenses/by/4.0/

Open Access

\begin{abstract}
The combined application of organic and mineral fertilizers can be a proper way of nutrition management to increase the yield and quality and to mitigate environmental impacts of chemicals and the pertaining costs. The impact of different rates of sulfur-containing humic acid was studied on yield and nutrient uptake of the fruits of olive "Zard" three-year-old trees in a trial based on a Randomized Complete Block Design with three replications in Shariati College of Tehran, Iran. The studied treatment was sulfur-containing humic acid at four rates of $0,20,25$ and $30 \mathrm{~kg} \cdot h \mathrm{a}^{-1}$, which was applied at two stages. The highest fresh weight, dry weight, chlorophyll $b$, carotenoid, $\mathrm{N}$ and $\mathrm{Cu}$ contents were related to humic acid rate of $20 \mathrm{~kg} \cdot \mathrm{ha}^{-1}$. The highest fruit length, chlorophyll $a$ and total chlorophyll were observed in control. The highest $\mathrm{K}, \mathrm{Fe}$ and $\mathrm{Mn}$ contents were obtained from plants treated with 30 $\mathrm{kg} \cdot \mathrm{ha}^{-1}$ humic acid. Plants treated with $25 \mathrm{~kg} \cdot \mathrm{ha}^{-1}$ exhibited the highest $\mathrm{P}$ and Zn contents. All in all, the application of sulfur-containing humic acid at different rates had favorable impacts on quantitative and qualitative traits of olive fruits.
\end{abstract}

\section{Keywords}

Humic Acid, Olive, Sulfur, Yield

\section{Introduction}

Olive (Olea europaea L.) is a species of hot and semi-hot regions originated from Syria, Southern Turkey and Palestine about 3000 BCE. It was domesticated 6000 years ago [1]. Olive is adapted to Mediterranean semi-arid conditions with the 
capability of growing in arid regions too, so that its cultivation is steadily growing in these regions [2]. Olive cv. "Zard" is a shrub with medium to tall size, circular crown, and relatively large, round fruits with $8 \mathrm{t} \cdot \mathrm{ha}^{-1}$ yield.

Organic farming is a system of agricultural production in its chemical fertilizers, pesticides, hormones and additives no synthetic chemical used to enhance fertility. Soil, control pests, diseases and weeds methods non-chemical such as crop rotation, green manure, biological control (And other non-chemical methods of pest and disease control and Weeds) compost and the like are used [3].

Organic crops contain less toxic chemicals than commercial products [4]. Soil organic nutrition is a global strategy to conserve natural fertility of soils through improving soil microorganisms [5]. Combined application of organic and mineral fertilizers can be a proper way of nutrient management to increase yield and quality and to reduce adverse environmental impacts of chemicals and the pertaining costs. Humic substances, e.g. humic acid and folic acid, cover a wide range of mineral organic compounds including amino acids, peptides, phenols, aldehydes, and nucleic acids in a bond with different cations and play an effective role in the improvement of plant growth and development in the composition of substrates and nutritional solutions [6].

Humus compounds of different organic matters contain two important organic acids-humic acid and folic acid. Humic acid is produced by the decomposition of organic matter, especially those with a plant origin, and can be found in soil, coal and peat resulting in the formation of stable, insoluble complexes with micronutrients. Folic acid forms soluble complexes with micronutrients. Humic acid is a mix of very large molecules with the capability of chelating elements and along with folic acid is a very important component of soil humus and is nontoxic to plants, animals and people. Humic acid is adapted to most chemical fertilizers and can be mixed with them. It is fully soluble in water and can be mixed with other liquid fertilizers, and it can be applied by soil application and with pressurized irrigation systems [7].

Humic acid directly acts as a quasi-hormonal compound [8] and indirectly improves soil physical condition, increases the metabolism of soil microorganisms, enhances root and stem growth [9], and increases the uptake of nutrients through its chelating, restoration and membrane infiltration conservation properties [10] [11]. As an organic acid derived from humus and other natural resources, humic acid has quasi-hormonal impacts [12] [13], induces the uptake of nutrients [14] [15] [16] and increases root and shoot biomass [7]. Humic acid is known to improve the uptake of soil nutrients and plant growth. It augments shoot: root ratio by increasing the generation of thin lateral roots in plants [15].

Ramazani et al. (2008) stated the consecutive fruit harvest for a long time on the one hand and insufficient nutrient supply to plants on the other hand as the main reasons for yield loss [17]. The buildup of organic matter in leaves is impossible if minerals are not present in photosynthesis process. Each macro element has a specific role in the metabolism of plants growth and development. The flowering of the plants is affected by nutritional status, and the balance be- 
tween materials the plants get from the air and soil (C:N ratio) is crucially important for flowering. The availability of ions is deeply influenced by $\mathrm{pH}$ because it affects their oxidation and solubility (e.g. in the case of phosphorus, sulfur and aluminum) or their controlling bioprocesses. In short run, the restoration of minerals from organic residues is the main, direct source of soluble minerals for soils [18].

Most plants need more phosphorus than sulfur [19]. Oilseed plants are among the species that have a high demand for sulfur. Sulfur is a component of the structures of methionine and cysteine amino acids, so it is involved in protein structure. In addition, it is involved in the formation of vitamins and glucoside and the activation of enzymes. Furthermore, sulfur is a part of phospholipids and thus, it directly contributes to the formation of fats [20].

Excessive use of chemical fertilizers and the consequent environmental pollution have led the mankind towards the use of the natural and organic fertilizers. Humic acid fertilizers improve the crop and yield by enhancing soil organic content and chelating nutrients. The present study was aimed to investigate the impact of sulfur-containing humic acid on quantitative and qualitative properties and the nutrients content of olive "Zard".

\section{Materials and Methods}

The study was carried out on three-year-old trees of olive "Zard" in Shariati College of Tehran, Iran on the basis of a Randomized Complete Block Design with three replications. The applied treatments included sulfur-containing humic acid (Khorram Bahar Atis company) at four levels of 0 (control), 20, 25, and $30 \mathrm{~kg} \cdot \mathrm{ha}^{-1}$ used as fertigation at two stages-in late-May after fruit setting (flower shedding and fruit formation) and in September during fruit filling. The recorded traits included yield, fruit fresh and dry weight, diameter and height, and their micronutrient and macronutrient contents.

To determine the yield of a tree, all its fruits were picked and were weighed to be expressed in grams. To measure fruit length and diameter, 10 fruits were randomly selected on each tree and their length and diameter were measured by a digital caliper.

Fresh weight was estimated by weighing the samples with a digital scale. Then, they were oven-dried at $80^{\circ} \mathrm{C}$ for 48 hours to get their dry weight.

Chlorophyll $a, b$ and $a+b$ and carotenoid contents of the fruits were estimated by Burns et al. (1992)'s procedure. Accordingly, $0.5 \mathrm{~g}$ of fruit sample was weighed and ground. Then, it was poured into a test tube and was added with 10 $\mathrm{ml}$ dimetyl sulfoxide. Next, the samples were over-dried at $75^{\circ} \mathrm{C}-80^{\circ} \mathrm{C}$ for three hours. Afterwards, $1 \mathrm{ml}$ of the solution was poured into another test tube and was reached to $5 \mathrm{ml}$ by DMSO addition. Finally, their absorptions were read at $480,663,645$ and $510 \mathrm{~nm}$ by a spectrophotometer.

To estimate nutrient absorption rates, the concentrations of $\mathrm{N}, \mathrm{P}, \mathrm{K}$ and micronutrients ( $\mathrm{Fe}, \mathrm{Mn}, \mathrm{Zn}$ and $\mathrm{Cu}$ ) were measured by Kjeldahl, calorimetry, flame photometry and atomic absorption method, respectively. 


\section{Results and Discussion}

\subsection{Yield}

Results analysis of variance showed that sulfur-containing humic acid influenced yield significantly at the $1 \%$ probability level (Table 1 ). Also, according to means comparison, the highest yield was related to humic acid rate of $25 \mathrm{~kg} \cdot \mathrm{ha}^{-1}$ and the lowest one to control (Table 2).

The application of humic acid improves soil physical structure, helps soil moisture retention, increases root permeability to water and nutrients, enhances the generation of nucleic acids and amino acids, improves plant enzymatic activity and metabolism, and consequently, improves yield [21]. The application of organic matter along with sulfur accelerates biooxidation of sulfur. Organic sulfur fertilization helps better plant growth by improving the absorbability of soil macro and micronutrients and enhances the quantitative and qualitative yield [22].

\subsection{Fruit Fresh and Dry Weight}

Analysis of variance revealed the significant impact of sulfur-containing humic acid on fruit fresh and dry weight at the $1 \%$ probability level (Table 1). Means comparison showed that the highest fruit fresh and dry weight was obtained from plants treated with $20 \mathrm{~kg} \cdot \mathrm{ha}^{-1}$ humic acid and the lowest ones from those treated with $30 \mathrm{~kg} \cdot \mathrm{ha}^{-1}$ (Table 2).

Humic acid improved the fresh weight of shoot and root of maize and pepper [23] [24]. The application of humic acid enhanced dry weight in strawberry [25], maize and oat [26], and wheat [27]. Results reflect the significant impact of foliar

Table 1. ANOVA the effect of sulfur-containing humic acid on measured characteristics of Olive.

\begin{tabular}{|c|c|c|c|c|c|c|c|c|c|c|}
\hline S.O.V & df & Yield & $\begin{array}{c}\text { Fresh } \\
\text { weight } \\
\text { fruit }\end{array}$ & $\begin{array}{c}\text { Fruit dry } \\
\text { weight }\end{array}$ & Length fruit & $\begin{array}{c}\text { Fruit } \\
\text { diameter }\end{array}$ & Chlorophyll a & Chlorophyll b & $\begin{array}{c}\text { Total } \\
\text { chlorophyll }\end{array}$ & Carotenoids \\
\hline Treatment & 3 & $23,311,549 \cdot 19^{\star *}$ & $0.378^{\star *}$ & $0.158^{\star *}$ & $12.802^{\star *}$ & $0.279 \mathrm{~ns}$ & $1.797^{\star}$ & $0.458 \mathrm{~ns}$ & $1.495 \mathrm{~ns}$ & $106.015^{\star \star}$ \\
\hline Error & 6 & $143,640.69$ & 0.01 & 0 & 0.24 & 0.3 & 0.26 & 0.1 & 0 & 0.6 \\
\hline $\mathrm{Cv}$ & & 6.273 & 3.8 & 11 & 2.03 & 3.3 & 6.96 & 7.2 & 5 & 2.9 \\
\hline
\end{tabular}

**, * and ns: Respectively significant difference and at $5 \%$ and $1 \%$ and non-significant.

Table 2. Mean comparison the effect of sulfur-containing humic acid on measured characteristics of Olive.

\begin{tabular}{|c|c|c|c|c|c|c|c|c|c|}
\hline Treatment & Yield & $\begin{array}{c}\text { Fresh } \\
\text { weight } \\
\text { fruit }\end{array}$ & $\begin{array}{l}\text { Fruit dry } \\
\text { weight }\end{array}$ & $\begin{array}{l}\text { Length } \\
\text { fruit }\end{array}$ & $\begin{array}{c}\text { Fruit } \\
\text { diameter }\end{array}$ & Chlorophyll a & Chlorophyll b & $\begin{array}{c}\text { Total } \\
\text { chlorophyll }\end{array}$ & Carotenoids \\
\hline $\mathrm{C}$ & $2814.3 \mathrm{c}$ & $2.54 \mathrm{a}$ & $0.78 \mathrm{~b}$ & $26.09 \mathrm{a}$ & $15.41 \mathrm{a}$ & $8.48 \mathrm{a}$ & $4.20 \mathrm{~b}$ & $12.68 \mathrm{a}$ & $31 b$ \\
\hline $\mathrm{H} 20$ & $4598 b$ & $2.67 \mathrm{a}$ & $1.13 \mathrm{a}$ & $25.95 \mathrm{a}$ & $15.65 \mathrm{a}$ & $6.89 b$ & $5.14 \mathrm{a}$ & $12.04 \mathrm{ab}$ & $33.59 \mathrm{a}$ \\
\hline H30 & $8350 a$ & $1.92 \mathrm{~b}$ & $0.57 c$ & $22.12 b$ & $15.02 \mathrm{a}$ & $6.92 \mathrm{~b}$ & $4.78 \mathrm{ab}$ & $10.98 b$ & $20.79 d$ \\
\hline
\end{tabular}

In each column, means with the similar letters are not significantly different at $5 \%$ level of probability using LSD test. 
application of different rates of humic acid on the fresh and dry weight of olive fruits. Researchers have reported the significant changes in shoot and root dry weight in plants treated with humic acid [7] [28] [29]. Given the role of sulfur in chlorophyll and chloroplast synthesis, root growth, stomatal opening, and photosynthesis, it can be concluded that higher fresh and dry weight in plants treated with sulfur-containing humic acid was related to the role of this element.

\subsection{Fruit Diameter and Length}

Analysis of variance showed the significant impact of sulfur-containing humic acid on fruit length at the $1 \%$ probability level, but it did not change fruit diameter significantly (Table 1). Means comparison showed that the highest length was related to control and the lowest one to humic acid rate of $30 \mathrm{~kg} \cdot \mathrm{ha}^{-1}$ (Table 3). The highest and lowest fruit diameters were obtained from humic acid rates of 20 and $30 \mathrm{~kg} \cdot \mathrm{ha}^{-1}$ (Table 2).

Foliar or powder application of humic acid resulted in longer and heavier roots in carrots and improved the growth of whole plant [30] that confirms our results.

\subsection{Chlorophyll a and b, Total Chlorophyll and Carotenoid}

As analysis of variance revealed, sulfur-containing humic acid significantly influenced chlorophyll a content at the 5\% probability level and carotenoid level at the $1 \%$ probability level, but it did not change chlorophyll $b$ and total chlorophyll content significantly (Table 1).

Sladky and Tichy (1959) observed that humic acid improved chlorophyll content of tomato leaves by $63 \%$ in plants grown in humic acid containing solution and by $15 \%$ in those grown in folic acid containing solution [31]. Foliar application of humic acid at $200 \mathrm{ml} \cdot \mathrm{l}^{-1}$ resulted in higher chlorophyll content of bell peppers [32].

Research shows that humic acid stimulates photosynthesizing activity in plants through increasing the activity of rubisco enzyme [33]. Given the critical role of plant hormones, especially cytokinin, in the fixation and increase of chlorophyll [34] and quasi-hormonal compounds (cytokinin) of humic matter [7] [8], the loss of chlorophyll content in plants treated with humic acid in the present study is inconsistent with other studies that show higher chlorophyll content under humic acid application.

\subsection{Macronutrients}

Results of analysis of variance indicated the significant impact of sulfur-con-

Table 3. ANOVA the effect of sulfur-containing humic acid on macronutrients and micronutrients of Olive.

\begin{tabular}{ccccccccc}
\hline S.O.V & df & Nitrogen & Phosphor & Potassium & Iron & Zinc & Copper & Manganese \\
\hline Treatment & 3 & $0.009^{* *}$ & $0.006^{* *}$ & $0.037^{* *}$ & $51,654.527^{* *}$ & $1398.083^{* *}$ & $33,673.416^{* *}$ & $137.46^{* *}$ \\
Error & 6 & $1 \mathrm{E}-05$ & 0 & 0 & 0.44 & 1.1 & 2.25 & 0.3 \\
Cv & & 1.052 & 4.71 & 0.3 & 0.33 & 1.1 & 0.81 & 2.2 \\
\hline
\end{tabular}

**, ${ }^{*}$ and ns: Respectively significant difference and at $5 \%$ and $1 \%$ and non-significant. 
taining humic acid on the measured macronutrient levels at the $1 \%$ probability level (Table 3 ). Means comparison revealed that the highest $\mathrm{N}$ content was related to humic acid rate of $20 \mathrm{~kg} \cdot \mathrm{ha}^{-1}$ and the lowest one to $30 \mathrm{~kg} \cdot \mathrm{ha}^{-1}$ humic acid. The highest $\mathrm{P}$ content was observed in plants treated with $25 \mathrm{~kg} \cdot \mathrm{ha}^{-1}$ humic acid. $\mathrm{K}$ content exhibited an increasing rate with humic acid so that the highest humic acid rate, i.e. $30 \mathrm{~kg} \cdot \mathrm{ha}^{-1}$, was related to the highest $\mathrm{K}$ content (Table 4).

Humic materials improve the synthesis of ion-transporting proteins and thus, increase uptake rate [35] [36].

This mechanism was confirmed by Nardi et al. (2000) in a study on MRNA of ion transporters in maize plants treated with humic acid [37]. In addition, humic acid improves the uptake of nutrients and the yield of plants via forming stable complexes with nutrients, especially micronutrients like Fe and $\mathrm{Zn}$ [15].

According to Nardi et al. (2002), humic acid is a natural polymer that helps the uptake of nutrients directly (as auxin or cytokinin quasi-hormones) or indirectly [7]. The application of humic acid in tomato hydroponic system influenced the uptake of calcium and potassium and the length of shoot and root in plants, but leaves and fruits differed in their contents of these nutrients. Humic acid improves $\mathrm{P}$ solubility in soil [38] and reduces $\mathrm{K}$ fixation in soil resulting in their higher uptake by plants [39]. The application of humic acid increased leaf N, P and chlorophyll content in tomato "Camarosa" [40].

Humic acid has been reported to stimulate and improve stomatal opening and leaf K content in potato "Golden Delicious" [41], lettuce [42], cucumber [43] and strawberry [44]. Higher $\mathrm{K}$ content can be related to the presence of $\mathrm{K}_{2} \mathrm{O}$ in humic acid composition and higher acidity of the solution given the fact that $\mathrm{K}$ is absorbed better in alkaline medium [45]. Higher alkalinity at higher rates of humic acid can be a reason for greater $\mathrm{K}$ uptake and $\mathrm{K}$ content in leaves [46].

\subsection{Micronutrients}

Analysis of variance showed that sulfur-containing humic acid affected the amount of the measured micronutrients significantly at the $1 \%$ probability level (Table 3). The highest Fe content was measured at humic acid rate of $30 \mathrm{~kg} \cdot \mathrm{ha}^{-1}$ and the lowest one was observed in control. The highest $\mathrm{Zn}$ content was observed in plants treated with $25 \mathrm{~kg} \cdot \mathrm{ha}^{-1}$ humic acid and the lowest one in those treated with $30 \mathrm{~kg} \cdot \mathrm{ha}^{-1}$ humic acid (Table 4).

Atiyeh et al. (2002) reported that the application of humic acid increased the concentration of micronutrients in tomato plants [9]. Humic acid treatment of

Table 4. Mean comparison the effect of sulfur-containing humic acid on macronutrients and micronutrients of Olive.

\begin{tabular}{|c|c|c|c|c|c|c|c|}
\hline Treatment & Nitrogen & Phosphor & Potassium & Iron & Zinc & Copper & Manganese \\
\hline $\mathrm{C}$ & $0.370 \mathrm{~b}$ & $0.44 \mathrm{~b}$ & $1.28 \mathrm{~d}$ & $87 d$ & $66.66 \mathrm{~d}$ & $78.66 \mathrm{~d}$ & $21.80 \mathrm{c}$ \\
\hline $\mathrm{H} 20$ & $0.380 \mathrm{a}$ & $0.52 \mathrm{a}$ & $1.48 \mathrm{c}$ & $102.33 c$ & $108.33 b$ & $325.66 \mathrm{a}$ & $22.70 \mathrm{bc}$ \\
\hline $\mathrm{H} 25$ & $0.30 c$ & $0.54 \mathrm{a}$ & $1.50 \mathrm{~b}$ & $242.33 b$ & $115.66 \mathrm{a}$ & $201.66 b$ & $23 b$ \\
\hline H30 & $0.26 \mathrm{~d}$ & $0.46 \mathrm{~b}$ & $1.52 \mathrm{a}$ & $366 a$ & $95.66 c$ & $137 \mathrm{c}$ & $36 a$ \\
\hline
\end{tabular}

In each column, means with the similar letters are not significantly different at $5 \%$ level of probability using LSD test. 
lime soil improved the uptake of $\mathrm{Zn}, \mathrm{Mn}$ and $\mathrm{Cu}$ by maize plants [47]. Humic materials chelate $\mathrm{Fe}$ and $\mathrm{Zn}$, resulting in their higher availability to plants [48]. As well, they improve the uptake of water and nutrients by plants through enhancing the permeability of root cells [21].

Rauthan and Schnitzer (1981) reported that the treatment of cucumbers with humic acid improved the uptake of $\mathrm{Fe}, \mathrm{Zn}, \mathrm{Cu}$ and $\mathrm{Mn}$ and that higher uptake of Fe and Mn enhanced chlorophyll content [43]. In a study on cut gerbera flowers, Nikbakht et al. (2008) observed that humic compounds (500 and $1000 \mathrm{mg} \cdot \mathrm{l}^{-1}$ ) resulted in higher Ca uptake than control [16]. The application of humic acid increased $\mathrm{Cu}$ content in cucumber [49]. Our results are consistent with other relevant research.

\section{Conclusions}

The ever growing population has forced mankind to over-exploit agricultural lands to meet food requirements. Consecutive use of soil has damaged its physical structure, causing the deficiency of nutrients. This deficiency is observed in plants grown in these lands, too. The application of such compounds as humic acid that improves the physical and chemical properties of soil can help us produce high-quality crops and avoid soil erosion. Sulfur-containing humic acid increased the fresh and dry weight and diameter of olive fruits. The better growth and physiological conditions of plants sprayed with sulfur-containing humic acid were related to their higher macronutrient $(\mathrm{N}, \mathrm{P}$ and $\mathrm{K}$ ) and micronutrient ( $\mathrm{Mn}, \mathrm{Zn}, \mathrm{Cu}$ and $\mathrm{Fe}$ ) contents. Consequently, we can produce high-quality crops by applying sulfur-containing humic acid.

\section{References}

[1] Montemurro, C., Simmeone, R., Pasqualone, A., Ferrar, E and Blabco, A. (2005) Genetic Relationships and Cultivar Identification among 112 Olive Accessions Using AFLP and SSR Markers. Journal of Horticultural Science and Biotechnology, 80, 105-110. https://doi.org/10.1080/14620316.2005.11511899

[2] Chartzoulakis, K., Loupassaki, M., Bertaki, M. and Androulakis, I. (2002) Effect of $\mathrm{NaCl}$ Salinity on Growth, Ion Content, and $\mathrm{CO}_{2}$ Assimilation Rate of Six Olive Cultivars. Scientia Horticulturae, 96, 235-247.

[3] Jafari, A., Mahlooji, M., Solhi, M. and Davazdahemami, S. (2007) Foundation, Principle and Challenges of Organic Farming. Sustainable Agriculture Quarterly, 4, 13 19.

[4] Mitchell, A.E. and Chassy, A.W. (2004) Antioxidants and the Nutritional Quality of Organic Agriculture. The American Journal of Clinical Nutrition, 76, 560-568.

[5] Guisquiani, P., Pagliani, M., Gigliotti, G., Businelli, D. and Bennetti, A. (1995) Urban Waste Compost: Effects on Physical, Chemical and Biochemical Soil Properties. Journal of Environmental Quality, 24, 175-182. https://doi.org/10.2134/jeq1995.00472425002400010024x

[6] Sebahattin, A. and Necdet, C. (2005) Effects of Different Levels and Application Times of Humic Acid on Root and Leaf Yield and Yield Components of Forage Turnip (Brassica rapa L.). Journal of Agronomy, 4, 130-133. https://doi.org/10.3923/ja.2005.130.133 
[7] Nardi, S., Pizzeghello, D., Muscolo, A. and Vianello, A. (2002) Physiological Effects of Humic Substances on Higher Plants. Soil Biology and Biochemistry, 34, 15271536.

[8] Zheng, Y., Graham, T., Richard, S. and Dixon, M. (2004) Potted Gerbera Production in a Subirrigation System Using Low-Concentration Nutrient Solutions. Horticultural Science, 39, 1283-1286

[9] Atiyeh, R.M., Lee, S., Edwards, C.A., Arancon, N.Q. and Metsger, J.D. (2002) The Influence of Humic Acids Derived from Earthworm-Processed Organic Wastes on Plant Growth. Bioresource Technology, 84, 7-14.

[10] Chen, Y. and Aviad, T. (1990) Effects of Humic Substances on Plant Growth. In: MacCarthy, P., et al., Ed., Humic Substances in Substances in Soil and Crop Science: Selected Readings, SSSA and ASA, Madison, WI, 161-186.

[11] Sanchez-Sanchez, A., Sanchez-Anderu, J., Juarez, M., Jorda, J. and Bermudez, D. (2002) Humic Substances and Amino Acid Improve Effectiveness of Chelate FeEDDHA in Lemons Trees. Journal of Plant Nutrition, 25, 2433-2442. https://doi.org/10.1081/PLN-120014705

[12] Vaughan, D. and Malcom, R.E. (1985) Influence of Humic Substances on Growth and Physiological Processes. In: Vaughan, D. and Malcom, R.E., Eds., Soil Organic Matter and Biological Activity, Martinus Nijhoff/Junk W, Dordrecht, The Netherlands, 37-75. https://doi.org/10.1007/978-94-009-5105-1_2

[13] Nardi, S., Concheri, G. and Dell'Agnola, G. (1996) Biological Activity of Humic Substance in Terrestrial Ecosystems. Elsevier, Amsterdam, 361-406.

[14] Visser, S.A. (1986) Effetto delle sostanze umiche sulla crescita delle piante. In: Burns, R.G., Dell'Agnola, G., Miele, S., Nardi, S., Savoini, G., Schnitzer, M., Sequi, P., Vaughan, D. and Visser, S.A., Eds., Sostanze Umiche. Effetti sul Terreno e sulle Piante, Ramo Editoriale degli Agricoltori, Roma, 96-143.

[15] Varanini, Z. and Pinton, R. (1995) Humic Substances and Plant Nutrition. In: Lüttge, U., Ed., Progress in Botany, Vol. 56. Springer, Berlin, 97-117.

[16] Nikbakht, A., Kafi, M., Babalar, M., Xia, Y.P., Luo, A. and Etemadi, N. (2008) Effect of Commercial Humic Acid on Plant Growth, Nutrients Uptake and Postharvest Life of Gerbera. Journal of Plant Nutrition, 31, 2155-2167. https://doi.org/10.1080/01904160802462819

[17] Ramazani, M., Talaei, A., Javadi, D. and Safarpoor, N. (2008) The Effect of Foliar Application of Some Nutrients on the Characteristics of Different Periods of Flowering and Fruit Set ROODBAR Local Varieties of Olive Trees. Research and Construction in Agriculture and Horticulture, 3, 46-52.

[18] Kafi, M., Borzooei, A., Salehi, M., Kamandi, A., Masoomi, A. and Nabati, J. (2009) Physiology of Environmental Stress in Plants. Publications University of Mashhad, $388 \mathrm{p}$.

[19] UL-Hassan, F., Hakim, Sh.A., Manaf, A., Qadir, G.H. and Ahmad, S. (2007) Response of Sunflower (Helianthus annuus L.) to Sulphur and Seasonal Variations. International Journal of Agriculture and Biology, 9, 499-503.

[20] Hrivna, L., Richter, R., Losak, T. and Hlusek, J. (2002) Effect of Increasing Doses of Nitrogen and Sulphur on Chemical Composition of Plants, Yields and Seed Quality in Winter Rape. Rostlinná Výroba, 48, 1-6.

[21] Dursun, A., Guvenc, I. and Turan, M. (2002) Effects of Different Levels of Humic Acid on Seedling Growth and Macro and Micronutrient Contents of Tomato and Eggplant. Acta Agrobotanica, 56, 81-88.

[22] Fayed, T.A. (2005) Effect of Some Organic Manures and Biofertilizers on Anna Ap- 
ple Trees. Yield and Fruit Characteristics. Egypt Journal of Applied Science, 20, 176-191.

[23] Gulser, F., Sonmez, F. and Boysan, S. (2010) Effects of Calcium Nitrate and Humic Acid on Pepper Seedling Growth under Saline Condition. Journal of Environmental Biology, 31, 873-876.

[24] Cordeiro, F.C., Catarina, C.S., Silveira, V. and De Souza, S.R. (2011) Humic Acid Effect on Catalase Activity and the Generation of Reactive Oxygen Species in Corn (Zea mays). Bioscience, Biotechnology, and Biochemistry, 75, 70-74. https://doi.org/10.1271/bbb.100553

[25] Arancon, N.Q., Edwards, C.A., Bierman, P., Welch, C. and Metzger, J.D. (2004) Influences of Vermicomposts on Field Strawberries: 1. Effects on Growth and Yields. Bioresource Technology, 93, 145-153.

[26] Sharif, M., Khattak, R.A. and Sarir, M.S. (2002) Effect of Different Levels of Lignitic Coal Derived Humic Acid on Growth of Maize Plants. Communications in Soil Science and Plant Analysis, 33, 3567-3580. https://doi.org/10.1081/CSS-120015906

[27] Sabzevari, S. and Khazaei, H. (2009) Effect of Foliar Application of Humic Acid Levels on Growth Characteristics, Yield and Yield Components of Wheat (Triticum aestivum L). Agroecology, 1, 52-63.

[28] Liu, C., Cooper, R.J. and Bowman, D.C. (1998) Humic Acid Application Affects Photosynthesis, Root Development, and Nutrient Content of Creeping Bentgrass. HortSci, 33, 1023-1025.

[29] Ferrara, G., Pacifico, A., Simeone, P. and Ferrara, E. (2008) Preliminary Study on the Effects of Foliar Applications of Humic Acids on "Italia" Table Grape. Journal International des Sciences de la Vigne et du Vin, 42, 79-87.

[30] Taylor, G. and Cooper, L. (2004) Humic Acid: The Root to Healthy Plant Growth. California State Science Fair, Project No. J1610.

[31] Sladky, Z. and Tichy, V. (1959) Applications of Humus Substances to Overground Organs of Plants. Biologia Plantarum, 1, 9-15. https://doi.org/10.1007/BF02927033

[32] Padem, H., Ocal, A. and Alan, R. (1999) Effect of Humic Acid Added Foliar Fertilizer on Quality and Nutrient Content of Eggplant and Pepper Seedlings. Acta Horticulturae, 491, 169-177. https://doi.org/10.17660/actahortic.1999.491.35

[33] Delfine, S., Tognetti, R., Desiderio, E. and Alvino, A. (2005) Effect of Foliar Application of N and Humic Acids on Growth and Yield of Durum Wheat. Agronomy for Sustainable Development, 25, 183-191.

[34] Gandabi, M., Hasanpoor Asil, M., Hatamzadeh, A., Rabiee, B. and Chamani, E. (2008) Effect of BA and STS on the Physicochemical Characteristics of Lilium Cut Flowers. Journal of Science and Technology of Agriculture and Natural Resources, 45, 603-612.

[35] Dell'Agnola, G. and Ferrari, G. (1971) Effect of Humic Acids on Anion Uptake by Excised Barley Roots. Proceedings of the International Symposium Humus et Planta $V$, Prague, 567-570.

[36] Dell'Agnola, G., Ferrari, G. and Nardi, S. (1981) Antidote Action of Humic Substances on Atrazine Inhibition of Sulphate Uptake in Barley Roots. Pesticide Biochemistry and Physiology, 15, 101-104.

[37] Nardi, S., Pizzeghello, D., Gessa, C., Ferrarese, L., Trainotti, L. and Casadoro, G. (2000) A Low Molecular Weight Humic Fraction on Nitrate Uptake and Protein Synthesis in Maize Seedlings. Soil Biology \& Biochemistry, 32, 415-419.

[38] Lobartini, J.C., Tan, K.H. and Pape, C. (1994) The Nature of Humic Acid Apatite Interaction Products and Their Availability to Plant Growth. Communications in 
Soil Science and Plant Analysis, 25, 2355-2369.

https://doi.org/10.1080/00103629409369193

[39] Salman, S.R., Abou-hussein, S.D., Abdel-Mawgoud, A.M.R. and El-Nemr, M.A. (2005) Fruit Yield and Quality of Watermelon as Affected by Hybrids and Humic Acid Application. Applied Sciences Research, 1, 51-58.

[40] Bazzoffi, P., Pellegrini, S., Rocchini, A., Morandi, M. and Grasselli, O. (1998) The Effect of Urban Refuse Compost and Different Tractors Tyres on Soil Physical Properties, Soil Erosion and Maize Yield. Soil and Tillage Research, 48, 275-286.

[41] Lopez, A.R. (1993) Humic Acid Effect on the Stomata Conductance and Leaf Abscission on Apple cv. Golden Delicious under Tropical Conditions. Acta Horticulturae, 329, 254-254. https://doi.org/10.17660/ActaHortic.1993.329.58

[42] Haghighi, M., Kafi, M. and Fang, P. (2012) Photosynthetic Activity and N Metabolism of Lettuce as Affected by Humic Acid. International Journal of Vegetable Science, 18, 182-189. https://doi.org/10.1080/19315260.2011.605826

[43] Rauthan, B.S. and Schnitzer, M. (1981) Effects of Soil Fulvic Acid on the Growth and Nutrient Content of Cucumber (Cucumus sativus) Plants. Plant and Soil, 63, 491-495. https://doi.org/10.1007/BF02370049

[44] Ameri, A. and Tehranifar, A. (2012) Effect of Humic Acid on Nutrient Uptake and Physiological Characteristic Fragaria ananassa var: Camarosa. Journal of Biodiversity and Environmental Sciences, 6, 77-79.

[45] Bidegain, R.A., Kammerer, M., Guiresse, M., Hafidi, M., Rey, F., Morard, P. and Revel, J.C. (2000) Effect of Humic Substances from Composted or Chemically Decomposed Poplar Sawdust on Mineral Nutrition of Ryegrass. Agriculture Sciences, 134, 259-267.

[46] Neri, D., Lodolini, E.M., Luciano, M., Sabbatini, P. and Savini, G. (2002) The Persistence of Humic Acid Droplets on Leaf Surface. Acta Horticulturae, 594, 303-314. https://doi.org/10.17660/ActaHortic.2002.594.36

[47] Hakan, C., Vahap Katkat, A., Bulent Asık, B. and Turan, M.A. (2011) Effect of Foliar-Applied Humic Acid to Dry Weight and Mineral Nutrient Uptake of Maize under Calcareous Soil Conditions. Communications in Soil Science and Plant Analysis, 42, 29-38.

[48] Lobartini, J.C., Orioli, G.A. and Tan, K.H. (1997) Characteristics of Soil Humic Acid Fractions Separated by Ultrafiltration. Communications in Soil Science and Plant Analysis, 28, 787-796. https://doi.org/10.1080/00103629709369830

[49] Sangeetha, M., Singaram, P. and Devi, R.U. (2006) Effect of Lignite Humic Acid and Fertilizers on the Yield of Onion and Nutrient Availability. 18th World Congress of Soil Science, Philadelphia, 9-15 July 2006. 
Submit or recommend next manuscript to SCIRP and we will provide best service for you:

Accepting pre-submission inquiries through Email, Facebook, LinkedIn, Twitter, etc. A wide selection of journals (inclusive of 9 subjects, more than 200 journals)

Providing 24-hour high-quality service

User-friendly online submission system

Fair and swift peer-review system

Efficient typesetting and proofreading procedure

Display of the result of downloads and visits, as well as the number of cited articles Maximum dissemination of your research work

Submit your manuscript at: http://papersubmission.scirp.org/

Or contact oje@scirp.org 